\title{
Social Issues and Identity Threat of the Sikh Minority Community in Malaysia
}

\author{
Sarjit S. Gill ${ }^{1}$, A. T. Talib ${ }^{1} \&$ Puvaneswaran Kunasekaran ${ }^{1}$ \\ ${ }^{1}$ Faculty of Human Ecology, University Putra Malaysia, Malaysia \\ Correspondence: Sarjit Singh Gill, Faculty of Human Ecology, University Putra Malaysia, 43400 Selangor, \\ Malaysia. Tel: 603-8946-7059. E-mail: sarjit@putra.upm.edu.my
}

Received: March 20, 2015 Accepted: March 30, 2015 Online Published: May 11, 2015

doi:10.5539/ach.v7n2p47 URL: http://dx.doi.org/10.5539/ach.v7n2p47

\begin{abstract}
This paper attempts to present the social issues and fading identity problem faced by the Sikh community in Malaysia. Past studies show that there are no significant researches done specifically to identify the negative elements of the community issues. Several studies done mainly focussing the Sikh identity and language issues without relating to the social problems faced by the minority community. Through a Focus Group Discussion (FGD) three main issues were identified. The issues of language fading, identity threat and mix marriages are found to be the major problems faced by the Sikh community in Malaysia. Thus, the findings of this study hoped to unveil the real problems of the minority community and would be addressed by the Sikh religious institutions and organizations. The Sikh organizations must also engage with the government agencies as equal partners to eradicate the social problems. The outcome shows that the Punjabi language is on the threat as dominated by other major languages namely English and Malay.
\end{abstract}

Keywords: Sikh, identity, social issues, minority problems

\section{Introduction}

The studies of Sikh community (Sarjit, 1999, 2005; Sarjit \& Charanjit, 2008) are new, especially in the fields of anthropology and sociology in Malaysia. Writings about Sikh issues not much prioritized by the Sikhs in Malaysia. This is because the religious aspect is regarded as individual rights and personal nature that felt inappropriate or sensitive to be discussed. The scenario created a clearer gap for the researchers to explore this issue. Sikhs in Malaysia also lack information and exposure to those Sikh studies. There are several studies of Sikh issues in Canada that are significant to the literature. A study of Buchignani and Indra (1989) explored the migration issues of the Sikh community in Canada. According to Sandhu (1970), no separate worthwhile records relating to Sikh immigration were kept either in India or in Malaya. Hence, a dire lack of discussion occurs on the Sikh minorities in Malaysia. It sorely begs for more work when compared to researches in India (especially Punjab), United States, Canada and Britain.

\section{Sikhism}

Sikh devotees salute with Waheguru Ji Ka Khalsa uttered, Waheguru Ji Ki Fateh (meaning the Khalsa is of God, the victory is to God) while bridging both hands to the chest when they met with other Sikh devotees. Typically, Sikh devotees visit Gurdwara on Sundays for religious pilgrims (congregational worship). But, this does not mean other days are not important because Sikh devotees pray every day. In the Sikh religion, all days are equally important and there is no day more special.

The Gurdwara, rituals that take place every day is the morning prayer (Japji Sahib), the evening prayer (Rehraas), and to close the night (Kirtan Sohila). Before entering the Gurdwara, Sikh devotees have to clean their hands and feet and cover their head if the individual does not wear a turban. After that, the Sikh devotees have to go to Darbar Sahib for metha tekhna (bow) by placing the forehead on the floor facing the Sri Guru Granth Sahib Ji. The act is a tribute to the greatness and glory of Sri Guru Granth Sahib Ji as the living Guru. After prostrating, Sikh women will sit on the floor on the left and Sikh men will be seated on the right. They sit politely facing the Sri Guru Granth $S a h i b J i$ and attention to religious rites conducted by the Granthi Sahib (Sarjit, 2001b: 46). The verses contained in Sri Guru Granth Sahib Ji are known as Gurbani, God's word. In short, the children are inspired and directions to Sikh devotees, spiritual discipline comfort in mind and spirits (Cole, 2003: 7).

In the Sikh religion, the congregational prayer is very important because the emphasis on equality between people regardless of gender, and is a basic (fundamental). Sikh teachers emphasize sadh distant to enhance the spirit of 
spirituality and unity among Muslims. Sikh religious ceremonies involved the reading of verses contained in Sri Guru Granth Sahib Ji. In short, collective worship is a religious obligation as important as performing Kirtan (singing of hymns), that singing religious songs, listening to katha (lecture), utter Simran (meditation) and read Ardas (prayer). This does not mean, individual prayer (private devotion) every day is not as important as making Simran. This emphasizes the practice of meditation to praise the greatness of Waheguru (God) humanity in order to obtain peace, guidance, guide and offer thanks to God. During the Granthi Sahib (religious specialist) religious messages, it's very gratifying to devote their full attention (Sarjit, 1999).

It should be noted here that all religious ceremonies concluded with the reading of Ardas where required to stand by bridging both hands, aimed gratitude, apology, thank you, or ask any intention of Waheguru. After praying, Granthi Sahib will read Hukumnama or Vaak (Waheguru message) while opening the Sri Guru Granth Sahib Ji and read the verse quoted on the page that opens. After that, Karah Parshad (pudding) given to disciples (Sarjit, 2001).

\section{Sikh Community in Malaysia}

There are several studies done specifically on the Sikh community and their socio-cultural and socio-economic issues. One of the major studies, done by Serjit Sahib Singh in 1992 reveals that the community is facing uphill task to retain their culture identity surrounded by other bigger and dominant communities. The scholar also argued the upcoming generation is weak and vulnerable in terms of culture and religion. Someeta Kaur Sidhu (1996) also agreed that the community is not strong as a unit. The Sikh people also could not cope with the rapid socio-economic development of the country and feel that the religious teachings are not practical. The fading of cultural and religious belief and practise can lead the younger generation to many social ills. According to Sikh Rehat Maryada (Sikh code of conduct), a Sikh is not allowed to consume alcohol. Through personal communication technique version 6 APA referencing system, opinions gathered to justify the current issues of the community.

\section{"Tobacco is not illegal for me. I do not go to Gurdwara nowadays. How to face the God when I smoke? (smiling). I thing no problem if I do not pray but I can't stop taking weed and beer" (personal communication, Minderjit Singh, 33 years old, Wangsa Maju)}

Rajjuddin and Jesbains (2010) argued that although there are numerous well known Sikh entrepreneurs and professionals such as Gulati's Silk Store, Euro Moda, Libaas Enterprise and Globe Silk Store, the community is still not perfect and not many members of the community are successful nowadays. The scholars also found that the youths of the community are also not interested in their parents business or professional jobs.

"My father was a lawyer but I do not want to be a lawyer. I should decide what I want to be. I am working as a teacher, but I am happy with my job although I am not as rich as my father, my salary is just 10\% of my father's salary. (personal communication, Bhupinder Singh, 27 years old, Semenyih)

This shows that the youths are not so worried about the economic status and are comfortable with their family assistance. They enjoy freedom to choose their life path and career. According to another key informant, the community is not living a happy lifestyle as seen by the outsiders. Thus this has created a gap to study what is the current socio-economic status of the Sikh community in Malaysia.

"We are not actually free of problems. I agree that most of our community members are stable in terms
of economic income. However, alcoholism is out of control. They (the men) are drinking almost every
day. I can't find a function without alcohol. I also can't find a function without fight." (personal
communication, Bhajan Kaur, 56 years old, Wangsa Maju)

The statement shows that alcohol is nothing new to the community. Gurcharan Singh (2013) also stated that alcoholism is a serious threat for the community that causes many families lost their fathers, brothers and husbands. The scholar also mentioned that alcoholism leads to many conflicts and fights especially after a wedding event or sports event. This unhealthy behaviour has created many negative implication on the community. This scenario could result into unhealthy activities as gangsterism, crime, theft and robbery which reveals Indians involvement in Klang Valley, Penang and Kuala Lumpur.

As a result the inequality income plays a dominant role in eradicating Indian ethnic to live in urbanisation development. Apparently due to low income of job, they find insufficient of capital to spend mainly for food, rent, transport and other necessary expenses. This situation arises from poor budgeting and unnecessary expenditure on 
alcohol and luxury goods (Jeyakumar, 2008). Today the rising cost of urban living make them to find new job opportunities or getting into unhealthy lifestyle (Sandhu, 1970).

According to the Alag Shabad Yug Trust Ludhiana (2010) there are several socio cultural issues of the Sikh community; apostasy, drug addiction, identity crisis and marriage issues. Apart from that, the free lifestyle, drug, alcohol and crime is increasing rapidly among the minority Sikh community in Canada (The Times of India, 2015).

Sarjit and Charanjit (2008) argued that the Gurdwara politics as one of the crucial factors that can influence the development of the community. The scholars also stressed that manipulation of power and authority by the Gurdwara committee members can suppress the advancement of the community. Thus the main socio-cultural problems of the Sikh community in Malaysia is still unknown. It can be concluded that there is no scientific research to identify the socio cultural issues and socio-economic status of Sikh community in Malaysia.

\section{Method}

This study is inductive in nature and employed a qualitative approach. A Focus Group Discussion (FGD) was conducted to gather key respondents' points on the social issues of Sikh's in Malaysia. The key respondents were selected based on their knowledge and expertise on the Sikh community. The discussion is transcribed and analyzed. In this case, the participants that were selected are the community experts and scholars who have great understanding of the Sikh history, identity and contemporary issues. However, they can be selected from both academic and practical areas. The reason of meticulous selection of the key informants is to gather important themes of socio-economic status and socio-cultural issues of the community.

\section{Analysis and Intepretation}

There are few issues raised by the respondents of the minority community. The issues are mainly related to the language, identity crisis and mix marriages.

\subsection{Language}

According to the respondents, the Punjabi language is slowly fading dominated by other dominant languages in Malaysia such as Malay and English.

"I was brought up in Kg Melayu environment so we speak Malay in every language we know. Example like: "Have you mandi, Have you makan and others" At one point I would avoid talking to another Sikh member because of language barrier. If $i$ see a Punjabi guy coming towards me, I rather cross the road and avoid him as I will say Sat Sri Akaal and after that I will speak in Malay. If he asks me further I can't answer so it would be safer by just crossing so he will not scold my mother later "Never taught this boy Punjabi language". That has given me inferiority complex to communicate. Then, I went to school, I was happy in school because my Bahasa Melayu was better than the Malay boys. Teachers would Say "Awak ni bukan Melayu macam mana Bahasa kamu petah sangat”. Then, I went to secondary school where in my class the majority was Chinese and there I pick up Cntonese, Mandarin and Hokkien. I Learn the Indian language as well. I learn all these for communication. But I left out my own, Punjabi Language." ( Male, 43 years old, Kuala Lumpur)

Another respondent from Sarawak also agreed that the language of the community is on threat. According to him, it is very soon that the Punjabi language will be forgotten.

"Most families in Sarawak speak English at home and they forget about their own language which is Punjabi. Even my own kids speak very poor Punjabi because we did not encourage them. We use to think Bahasa Melayu and English is important in school and Punjabi is not so important. I was reading the Malaya Samachar- A Punjabi newspaper established in the 60-70 years ago. According to the paper, In 50 years, the Punjabi language will vanish because of the trend going on now." (Male, 67 years old, Sarawak)

The conversations show that the issue of language fading is serious. The language of the minority Sikh community should be preserved and practised with no curiosity and shyness especially by the youths.

\subsection{Identity Crisis}

The respondents are also generally agreed that the Sikh identity is on threat. Many youths in the country are not wearing Turbans which is one of the main identity of the community worldwide. 
"My father is very strict. He is from the army. I have three siblings. They all carriy Sikh identities but they are not happy (not genuine). My brother is just wearing a turban to make my father happy. He understands Punjabi but does not go to Gurdwara. He just does things as the parents asked to. He was forced to do it until he was free. Due to the strictness in my family my siblings do not tell and inform anything about their life to my parents. So, as an elder sister, they tell me and ask me to pass the message to my father." (Female, 39 years old, Kuala Lumpur)

The statement above clearly shows that the youths are not genuinely happy with the identity that they have to carry in the modern world. Thus, a good strategy to approach the youths to understand the Sikh identity holistically must be taken by various stakeholders namely Gurdwara as a religious institution.

\subsection{Mix marriages}

According to some of the respondents, mix marriages will not lead to a successful life of the family. The couple with different religious beliefs and understandings could not keep their family relationship together.

"I was working in Standard Chartered and met a colleague named Ranjit Kaur. Her features were more to Indian. Her mum was an Indian and her dad was a Punjabi. She could not speak any Punjabi at all. She was having an identity crisis. When people come to the bank especially elderly Punjabis, they speak to her in Punjabi and she will shy away as only her name is Punjabi but she could not speak. She says her father did not speak in Punjabi at all. She wishes to learn the language but no one taught her and her mother speaks in Tamil. She also said she wishes to marry a Punjabi man with full Identity but unfortunately, now she has converted to Christians. Punjabis those days -20 years back do not accept Inter Marriages so she ended up being a Christian as she was having a lot of confusion." (Female, 39 years old, Kuala Lumpur)

This experience was also supported by another respondent saying that the mix marriages will lead to confusion of for the children of the couple.

"They can meet, fall in love and get married with or without the consent of both families. But, imagine the confusions their children will go through in the future. the chilren will fllow which teaching? they will end up confused and disengaged with their family, religion and community." (Female, 58 years old, Kuala Lumpur)

However, another respondent argued that mix marriage is not a threat to Sikh people.

"In Sikhism, we do not force people. Let them choose their partners. I know many people who married other religion partners are living happily. Are you saying that the Punjabi couples (same religion) are not leading to divorce. Many of our people are facing divorce issue" (Melaka, 58 years old, Kuala Lumpur)

However, generally all the respondents agreed that the community is not happy with mix marriages as it can lead to many issues such as apostasy and divorce.

"Many foreigners from Pakistan and India are coming to Malaysia. They try to find local Punjabi girls, marry them and try to stay in Malaysia and there are consequences we have to bear. After some time they just leave their wives and disappear. who is going to take care of the family?" (Female, 53 years old, Ipoh)

Thus, it can be said that mix marriages are still seen as a negative happening by the Sikh community. The family that went through mix marriages will be also isolated by some members of the community. The mix marriages issue is quite rampant and to some extent some Gurdwaras have started to compromise and accept the marriage ceremony to be conducted in the Gurdwara.

\section{Conclusion}

The issues of the Sikh community in Malaysia are not exposed well. The community in Malaysia although small in numbers, still strongly practise their religious teachings. In this study however, it was found that the language of the community is on the threat as dominated by other major languages. The community also felt that their identity is fading and should be practised consistently especially by the youths. Mix marriages is also found to a major issue of the community. Mix marriages which lead to religious confusion is believed can affect the next generation of the family institution. 


\section{Acknowledgments}

This research is funded by Coalition of Malaysian Sikh Organisations.

\section{References}

Alag Shabad Yug Trust. (2013). Socio Cultural Problems encountering Sikh Sangat. Retreived on October 3, 2013, from http://www.sikhglory.alagshabadyug.org/problems.php

Buchignani, N., \& Indra, D. M. (1989). Key issues in Canadian-Sikh ethnic and race relations: implications for the study of the Sikh diaspora.In N. G. Barrier, \& V. Dusenbery (Eds.), The Sikh Diaspora: Migration and Experience Beyond the Punjab (pp. 141-184). Delhi: Chanakya Publications.

Cole, W. Owen. (2003). Teach Yourself Sikhism. London: Hodder Headline.

Gurcharan, S. (2013). Alcohol - a Sikh Social Problem in Malaysia. Sikh Philosophy Network. Retreived November 2, 2013, from http://www.sikhphilosophy.net/people-and-opinion/41428-alcohol-social-disease -many-malaysian-sikhs.html

Jeyakumar, D. (1993). The Indian poor in Malaysia: problems and solutions. Indian communities in Southeast Asia, 405-437.

Krueger, R. A. (2009). Focus groups: A practical guide for applied research. Sage.

Nair, S. (2006). Poverty in the New Millennium - Challenges For Malaysia. Faculty of Economics and Administration, University of Malaya.

Rajuddin, M. R., \& Kaur, J. (2010). Faktor-Faktor Yang Mempengaruhi Pembangunan Kaum Sikh Dalam Bidang Keusahawanan Di Bandaraya Kuala Lumpur. Faktor-Faktor Yang Mempengaruhi Pembangunan Kaum Sikh Dalam Bidang Keusahawanan Di Bandaraya Kuala Lumpur, 1-14.

Sandhu, K. S. (1970). Sikh immigration into Malaya during the period of British rule. In J. Ch'en \& N. Tarling (Eds.), Studies in the social history of China and South-East Asia (pp. 335-354). Cambridge: Cambridge University Press.

Sarjit S. G. (2001). Perkahwinan campur peranakan Punjabi di Sabah. Sari 19: 189-203.

Sarjit, S. G. (1999). Diaspora dan masalah identiti Sikh di Malaysia. Akademika, 55, 183-192.

Sarjit, S. G. (2001). Perubahan Sosio-Budaya dan Kesannya Terhadap Identity Komuniti Sikh di Malaysia: Satu Perbincangan Kritis. Prosiding Pembentukan Identiti: Sebuah Wacana. Shamsul Amri Baharuddin (Penyusun), Hlm, 44-52.

Sarjit, S. G. (2005). Peranan Gurdwara dalam pembentukan identity Sikh di Malaysia: Satu kajian perbandingan $(P h D)$. Universiti Kebangsaan Malaysia.

Sarjit, S. G., \& Charanjit, K. (2008). Gurdwara and its politics: Current debate on Sikh identity in Malaysia. SARI: Jurnal Alam dan Tamadun Melayu, 26, 243-255.

Serjit, S. S. (1992). Krisis identiti di kalangan komuniti peranakan Punjabi yang beragama Sikh: satu kajian kes di Pantai Barat Sabah. Latihan Ilmiah. Universiti Kebangsaan Malaysia.

Siwar, C., \& Kasim, Y. (1997). Urban Development and Urban Poverty in Malaysia. International Journal of Social Economics, 24(12), 1524-1535.

Someeta Kaur Sidhu (1996). Kebangkitan semula agama Sikh: Satu kajian kes di Kuala Lumpur. Latihan Ilmiah. Universiti Kebangsaan Malaysia.

Tashakkori, A., \& Teddlie, C. (Eds.). (2003). Handbook of mixed methods in social \& behavioral research. Sage.

The Times of India,. (2015). Canadian Sikh Leads 'Drug Awareness Walk Across Canada' - The Times of India. Retrieved 11 May 2015, from http://timesofindia.indiatimes.com/nri/us-canada-news/Canadian-Sikh-Leads Drug-Awareness-Walk-Across-Canada/articleshow/8662589.cms

\section{Copyrights}

Copyright for this article is retained by the author(s), with first publication rights granted to the journal.

This is an open-access article distributed under the terms and conditions of the Creative Commons Attribution license (http://creativecommons.org/licenses/by/3.0/). 